\title{
O internacionalismo sindical na era de Seattle
}

The Trade Union Internationalism in the Age of Seattle

Le internationalisme syndical à l'ère de Seattle

\section{Peter Waterman}

Tradutor: Teresa Tavares

\section{(2) OpenEdition}

\section{Journals}

\section{Edição electrónica}

URL: http://journals.openedition.org/rccs/1298

DOI: $10.4000 /$ rccs. 1298

ISSN: 2182-7435

\section{Editora}

Centro de Estudos Sociais da Universidade de Coimbra

Edição impressa

Data de publição: 1 Junho 2002

Paginação: 33-68

ISSN: 0254-1106

\section{Refêrencia eletrónica}

Peter Waterman, "O internacionalismo sindical na era de Seattle », Revista Crítica de Ciências Sociais

[Online], 62 | 2002, colocado online no dia 01 outubro 2012, criado a 30 abril 2019. URL : http:// journals.openedition.org/rccs/1298; DOI : 10.4000/rccs.1298 


\section{PETER WATERMAN}

Institute of Social Studies, Haia

\section{O internacionalismo sindical na era de Seattle ${ }^{1}$}

Reconhecendo a existência de uma profunda crise mundial que atravessa a esfera do trabalho, este texto propõe: uma crítica do internacionalismo sindical do período nacional/industrial/colonial; uma reconceptualização do sindicalismo e do internacionalismo operário adequada a um período de capitalismo globalizado/conectado em rede/informatizado; o diálogo do milénio sobre a esfera do trabalho e a globalização; uma das novas abordagens académicas da esfera do trabalho a nível internacional e do internacionalismo operário; o papel da comunicação, da cultura e das novas tecnologias da informação e da comunicação. A conclusão salienta a centralidade da interconectividade reticular, da comunicação e do diálogo para a criação de um novo internacionalismo operário.

\section{Introdução}

É sobejamente reconhecido, tanto no interior do movimento operário como à sua volta, que a esfera do trabalho (entendida na sua múltipla acepção de trabalho assalariado, de uma identidade de classe, de actividade sindical, de interlocutor com voz activa nas relações com a indústria, de movimento social democrático-radical, e de parte integrante da sociedade civil) vive hoje uma crise profunda. E isso é tanto mais verdade quando ele é entendido como movimento internacional numa época em que a velha ordem capitalista internacional se vê confrontada com os desafios colocados pela nova desordem capitalista global. A recuperação desta situação vai exigir não só

\footnotetext{
${ }^{1}$ O presente texto é uma versão preliminar de um artigo entretanto publicado num volume organizado por Waterman e Wills (2001), e retoma, actualiza e desenvolve um extenso texto baseado num trabalho em curso (Waterman, 1999) bem como investigação já publicada em forma de livro (Waterman, 1998a e 2001a). Além disso, tem por base um conjuto de diversos outros artigos, recensões e reflexões inéditas (Waterman, 1998b). A maior parte destes materiais pode ser consultada na página Global Solidarity Dialogue/Dialogo Solidaridad Global (cuja referência é fornecida na secção Websites, no final deste texto). Os meus agradecimentos a Kim Scipes, a Bruce Nissen e, em especial, a Dan Gallin e Jane Wills, pelos seus comentários a versões anteriores do artigo. Se de alguma maneira descurei ou entendi mal as perspicazes sugestões que me fizeram em privado, espero ter oportunidade de, em público, poder vir a responder às suas reacções.
} 
uma crítica do internacionalismo operário tradicional, mas também todo um trabalho de reconceptualização, além de novos tipos de análise e um novo diálogo - e uma dialéctica nova - entre as partes interessadas. Para tanto, aqui se adiantam, uma após outra, as seguintes propostas: 1) uma crítica do internacionalismo sindical do período nacional/industrial/colonial (NIC) ${ }^{2}$; 2) uma reconceptualização do sindicalismo e do internacionalismo operário adequada a um período de capitalismo globalizado/ conectado em rede/informatizado (GCI); 3) o diálogo do milénio sobre a esfera do trabalho e a globalização; 4) uma das novas abordagens académicas da esfera do trabalho a nível internacional e do internacionalismo operário; 5) o papel da comunicação, da cultura e das novas tecnologias da informação e da comunicação (TIC). A conclusão salienta a centralidade da interconectividade reticular, da comunicação e do diálogo para a criação de um novo internacionalismo operário.

\section{Internacionais sindicais e o período nacional/industrial/colonial ${ }^{3}$}

Existiram e existem ainda outros tipos de organização sindical "internacional" para além daquelas que aqui me proponho tratar: uma organização de inspiração social-cristã e de implantação pouco mais que marginal, actualmente com a designação World Confederation of Labour (WCL - Confederação Mundial do Trabalho, CMT); organizações autónomas regionais, como a Organisation of African Trade Union Unity (Organização para a Unidade Sindical Africana); e inclusivamente a US American Federation of Labour-Congress of Industrial Organisations (AFL-CIO - Federação Americana do Trabalho-Congresso das Organizações da Indústria), que durante dezenas de anos funcionou como se fosse uma internacional paralela e concorrente, a que não faltavam as respectivas instâncias e dinâmicas regionais! Terei, no entanto, que me circunscrever ao caso da International Confederation of Free Trade Unions (ICFTU - Confederação Internacional dos Sindicatos Livres, CISL) e a duas outras estruturas que com ela mantêm ou mantiveram importantes relações. A World Federation of Trade Unions (WFTU - Federação Sindical Mundial, FSM), representante da tradição comunista de internacionalismo sindical e que foi a grande rival político-ideológica da CISL durante a Guerra Fria; e a ITF, International

\footnotetext{
${ }^{2}$ Ver lista das siglas principais no final do texto (nota do tradutor).

${ }^{3}$ A análise que se segue deve ser cotejada com a que é feita por Dan Gallin (1999a), que na qualidade de antigo Secretário da International Union of Food and Allied Workers (IUF - Sindicato Internacional dos Trabalhadores da Alimentação e Associados) tem marcado presença, não só de forma activa como através das suas reflexões críticas, no internacionalismo operário e sindical. A este propósito $v$. também Gallin (1999b, 2001).
} 
Transportworkers Federation (Federação Internacional dos Trabalhadores dos Transportes, FITT), um dos grandes Secretariados Profissionais Internacionais (ITSs - SPIs) ligados à área da indústria. Representando um tipo de internacional anterior à CISL, a FITT foi e continua a ser marcada por uma certa concorrência com a CISL e com o seu sindicalismo baseado no Estado-nação. A vitória político-ideológica da CISL na Guerra Fria e o estado de confusão ou crise em que mergulhou com o advento da globalização neoliberal deixam ainda em aberto, pelo menos, a questão de saber se é nas internacionais de matriz nacional ou nas de matriz industrial - ou noutras de natureza inteiramente diversa - que reside a resposta mais adequada com vista a um novo internacionalismo sindical, operário ou geral na presente era de globalização ( $v$. adiante).

A Confederação Internacional dos Sindicatos Livres é uma organização centenária com uma longa tradição atrás de si. Apoiada pela esmagadora maioria dos sindicatos nacionais dos países do Norte e tendo saído vitoriosa da guerra fria no terreno sindical, ela recrutou para as suas fileiras os maiores sindicatos nacionais radicais dos países do Sul. Além disso, reclama para si um número de membros que ascende aos 124 milhões, perfilando-se para vir a incorporar ainda, no futuro, os da China e da Rússia. ${ }^{4}$ Sendo assim, por que razão é posta hoje em causa, vivendo, inclusivamente, num estado de autoquestionamento? Porque esta confederação internacional continua, em minha opinião, a ser a expressão do capitalismo nacional/ industrial/colonial (NIC) que lhe deu o ser e a forma. A CISL é uma confederação internacional de federações sindicais de carácter nacional(ista), por sua vez representantes históricas do operário (do sexo masculino) da indústria pertencente às grandes empresas capitalistas ou estatais e desejosas de obterem da parte do patronato ou dos respectivos governos o devido reconhecimento, protecção e representação não só ao nível do próprio Estado-nação como ao nível dos demais Estados. É esta uma tradição que coexiste em simultânea cooperação e concorrência com o taylorismo (a linha de montagem de produção em massa), o fordismo (em que os trabalhadores recebem o mínimo necessário para que possam tornar-se consumidores em massa dos produtos que ele próprios fabricam), o keynesianismo (em que a redistribuição social e a riqueza são determinadas pelos índices de crescimento) e o nacionalismo de Estado (em que os trabalhadores são

\footnotetext{
${ }^{4}$ A principal fonte para conhecer a história da CISL é van der Linden (2000). Sarah Ashwin (2000) propõe uma crítica informativa e perspicaz do último período desta organização, em especial no que se refere às suas relações com o antigo mundo comunista. Esta autora suscita a questão de estar presentemente a CISL a aproximar-se de um "sindicalismo de movimento social" (113), noção a que regressarei adiante. $V$. também Gallin (1999a).
} 
encarados como cidadãos nacionais, isto é, como alguém que se define por uma relação de oposição, de concorrência e até mesmo de guerra com os demais). A ideologia, as instituições e os procedimentos associados à ideia de "parceria social" passaram a ser hegemónicos depois da criação, em 1919, da International Labour Organisation (ILO - Organização Internacional do Trabalho, OIT), debaixo de uma considerável pressão do movimento operário. A CISL interiorizou a natureza tripartida da OIT. ${ }^{5}$ A essa natureza tripartida veio juntar-se, durante o período da Guerra Fria, a ideologia do sindicalismo "livre", o que levaria à tendência para identificar a CISL com o "mundo livre" liderado pelos Estados Unidos da América. ${ }^{6} \mathrm{~A}$ isso acresceu ainda, agora que se assistia ao desmoronamento do colonialismo (de que a CISL foi cúmplice), a ideologia do "desenvolvimento" a caminho de uma utopia social, implicitamente inspirada quer num certo modelo de tipo sueco, quer na cornucópia de riqueza e abundância oferecida pelo modelo californiano. A organização internacional foi edificada segundo a matriz da época, ou seja, em termos de um corpo assente no Estado-nação e que formalmente se apresentava com sendo democrático-representativo, além de primordialmente vocacionado para a concorrência/cooperação com as outras internacionais sindicais e para a actividade de "lobbying" dos órgãos inter-estatais. O internacionalismo daqui resultante foi um "internacionalismo nacional", traduzido na conquista de direitos e de padrões sociais-democratas no interior do Estado-nação democrático-liberal e na conquista desses mesmos Estados-nação por parte dos trabalhadores a quem eles eram negados (casos da África do Sul do Apartheid e da Polónia comunista).

Por ocasião do $50 .^{\circ}$ aniversário da CISL, um número especial da Trade Union World (1999), revista oficial da organização, apresentava-se com o seguinte título: "Como a CISL Influenciou os Grandes Desenvolvimentos a Nível Global ao Longo dos Anos". A verdade, porém, é que a impressionante história recente da CISL (Linden, 2000) - que comunga desta perspectiva institucional-desenvolvimentista - revela estar este seu meio século de existência recheado de aspectos muito problemáticos, nomeadamente no que refere à manutenção de relações estreitas e até simbióticas com determinados Estados, com o capital, com impérios e blocos (dentro do próprio mundo ocidental!), e inclusivamente com os respectivos servi-

\footnotetext{
5 A palavra "tripartido" sugere uma tarte partida em três partes iguais. Em termos de poder relativo, no entanto, o melhor símbolo da OIT deveria antes ser um bolo em camadas, uma vez que, cabendo $50 \%$ ao Estado (ou "governo") e $25 \%$ ao Capital (os "empregadores"), resta aos Sindicatos (o "mundo do trabalho") os $25 \%$ do fundo.

${ }^{6}$ Há alguns anos a CISL mudou o título da sua revista oficial de Free Labour World para Trade Union World, parecendo dar assim mostras de reconhecer as ambiguidades e limitações da palavra "livre".
} 
ços de espionagem. Igualmente posta a nu, e de igual modo problemática, é a dimensão da dependência da política da CISL relativamente às principais organizações nórdicas nela filiadas, bem como das lutas intestinas - ainda que habitualmente discretas ou ocultas - travadas entre os seus principais sindicatos e funcionários. Com efeito, a leitura deste livro deixa-nos com a sensação de que a CISL não corresponderá propriamente à tradição mais marcante e à força impulsionadora mais significativa do movimento operário internacional, revelando-se antes como uma agência ou grupo de pressão internacional com ligações a outras organizações de empregadores nacionais e inter-estatais, divorciado do quotidiano concreto dos operários e do trabalho destes nas fábricas. Esse sentimento é reforçado pela leitura da Conclusão do capítulo correspondente ao período 1972-década de 90, onde se citam as palavras de um proeminente dirigente nacional nórdico proferidas no Congresso de 1975:

Não sei qual é o número de pessoas nos vossos países que têm uma consciência profunda da existência da CISL, mas eu pessoalmente desconfio que no meu próprio país esse número é muito reduzido... (516)

Rebecca Gumbrell-McCormick, autora do capítulo em causa - que de resto assume as dimensões de um livro - (2000), admite este reparo e reconhece, ela própria, outras limitações. Contudo afirma que

muitos trabalhadores em África, no Chile ou noutras regiões em conflito, onde colegas seus têm sido presos ou assassinados e outros têm sido salvos através da intervenção da CISL ou das suas organizações filiadas, terão por certo a consciência perfeita da existência desta, quer a conheçam pelo nome ou não. (517)

Mesmo admitindo que assim é, estas palavras sugerem uma entidade que tem mais a ver com o Comité Internacional da Cruz Vermelha do que com uma organização internacional do tipo movimento social (para usar uma bem apropriada expressão americana). Há que evitar demonizar a CISL ou minimizar-lhe a importância. Se tivesse sido vontade dos trabalhadores ter uma CISL (ou um qualquer organismo sindical internacional) de tipo diferente, ter-se-iam organizado no sentido de atingir esse objectivo. Tem, pois, talvez todo o cabimento ver a CISL como uma estrutura de cunho defensivo e autolimitativo. Uma estrutura que, além disso, funciona no âmbito e sob a alçada do capitalismo NIC, não obstante encontrar-se sujeita à concorrência do sindicalismo comunista do Leste e do sindicalismo radical-nacionalista/populista do Sul. 
Apesar de ter sofrido um quase completo desmoronamento, e de quase não ter hoje uma existência digna desse nome, a referida concorrência comunista continua a não ser desprovida de interesse. As origens da Federação Sindical Mundial remontam à aliança inter-estados (os Aliados) que derrotou a aliança fascista (o Eixo) na II Guerra Mundial. ${ }^{7}$ Mas essas origens residem também na vaga de empatia popular, operária, democrática, nacionalista e revolucionária que acompanhou essa vitória. Que a dinâmica do movimento se subordinou à dinâmica inter-estatal, mostra-o a velocidade com que, entre 1947 e 1949, a FSM se fracturou em função das linhas de divisão criadas pela Guerra Fria. Mas a rapidez com que essa fractura se deu deveu-se igualmente a uma guerra fria anterior a essa: uma guerra que opusera os sindicatos sociais-democratas aos comunistas e que remontava aos tempos em que os comunistas fundaram o Profintern, ou Internacional Vermelha de Sindicatos (RILU - IVS), no ano de 1920 (MacShane, 1992). Após a fractura de 1949, a FSM assegurou, para além dos sindicatos controlados pelo Estado pertencentes ao bloco comunista, o domínio dos sindicatos ocidentais com direcções comunistas, e também dos sindicatos comunistas e de alguns dos sindicatos de orientação radical-nacionalista dos países do Sul. Ao procurar expandir-se para esta região do mundo, de aspecto tão promissor, a FSM acabaria por reproduzir - ainda que com uma inferior probabilidade de êxito - as relações clientelares dos sindicatos do Ocidente. As actividades de solidariedade, de divulgação e de formação que então desenvolveu visavam mais o recrutamento de aliados para o mundo comunista entre os meios sindicais e o aparelho estatal do que o aumento da combatividade, da autonomia e da consciência de classe, a confrontação com o capitalismo, ou o derrube do Estado autoritário (com a excepção dos Estados subordinados ao Ocidente). Assim, e a título de exemplo, veja-se como, ao longo de 50 anos de história, a FSM "revolucionária” nunca produziu nada sobre o tema de como organizar uma greve, fosse de âmbito nacional ou internacional. ${ }^{8}$ De facto, a principal actividade da FSM parece ter-se resumido à organização de congressos internacionais, todos eles marcados pelo apelo à "reunificação do movimento sindical internacional" e pela reiterada conclusão sobre a necessidade de reunir um novo congresso.

\footnotetext{
7 Que eu saiba, a história da FSM ainda não mereceu da parte da Universidade a atenção que a questão merece. Carew (2000) é autor de um breve mas equilibrado estudo sobre o tema. A caracterização que aqui faço baseia-se em parte na minha própria experiência a trabalhar para a FSM na área da formação sindical em Praga, entre 1966 e 1969. A partir de então tornei-me numa espécie de observador permanente da FSM.

${ }^{8}$ Com efeito, a última vez que o sindicalismo comunista internacional levou a cabo um esforço do género parece ter sido durante o período da "Classe contra Classe" do Comintern, no final da década de 20 (National Minority Movement, s.d.).
} 
Na altura da invasão soviética da Checoslováquia, em 1968, o operariado checo não quis saber da FSM - de cuja existência, de resto, não tinha sequer consciência -, não obstante esta se encontrar sediada em Praga. O Secretariado da FSM encheu-se momentaneamente de alguma coragem democrática e proletária ao condenar a invasão, tendo sido provavelmente a única organização frentista internacional de orientação comunista que alguma vez criticou a União Soviética. Contudo, esse pequeno gesto de autonomia, que já de si pecou por tardio, iria ser completamente anulado no decurso de uma reunião do Conselho realizada alguns meses depois. Quando o representante de um sindicato maoista japonês se preparava para falar, foi-lhe desligado o equipamento de tradução automática, facto bem revelador da falência desta organização precisamente no mesmo ano em que, por todo o mundo, o autoritarismo e o conservadorismo eram postos em causa nas ruas.

A FSM continua, hoje, a existir, e a existir num duplo sentido, qual deles o mais problemático. Em primeiro lugar, existe sob a forma de um número de escritórios modestos e de funcionários modestamente pagos, e de uma série de congressos e de publicações extraordinariamente parecidos com os de há 30 anos atrás. Em segundo lugar, ela persiste como mito, perpetuado por sindicalistas de esquerda, activistas militantes, ou anti-imperialistas, bem como por alguns investigadores de esquerda da nova geração. Poderia pensar-se que estes buscam uma alternativa à CISL, fazendo-o, contudo, olhando para trás e para o lado em vez de olharem para a frente. O único sinal de que a FSM aprendeu alguma coisa com as lutas travadas contra o capitalismo contemporâneo foi a criação, em 2000, do seu "website" (v. Websites, no final). Mas esse "sítio" na "Web" é também a prova viva de que a FSM continua a estar fortemente dependente da participação de sindicatos controlados pelo Estado, provenientes do que resta dos países comunistas e do mundo árabe. Quanto ao mais, este resquício da tradição romântica e insurreccional - mas também típica do socialismo de Estado - parece querer regressar ao mundo dos Estados-nação que lhe esteve na origem.

A busca de alternativas à CISL é hoje marcada por preocupações e desafios de uma bem maior contemporaneidade. Um deles tem a ver com aquilo que deve ser o papel de uma confederação literalmente internacional em tempos de globalização. A CISL é uma instituição formalmente enfeudada a sindicatos de índole nacional(ista), e enfeudada também - considerando o que sempre foi a sua política, historicamente dominada pelo poder e pelo dinheiro - aos seus membros mais ricos e poderosos. Além disso, situa-se no cume de uma estrutura em pirâmide que a coloca a uma distância considerável - e multiplamente filtrada - dos verdadeiros 
operários, gente de carne e osso. ${ }^{9}$ A CISL é, ademais, uma instituição solidamente incrustada num universo tradicional composto por instituições inter-estatais, que dispende muitas das suas energias a fazer lóbi junto destas. O segundo grande problema, a meu ver, é a invisibilidade da CISL. Pense-se no que é uma organização com 124 milhões de membros - um número, ainda por cima, em expansão -, mas com uma presença absolutamente nula na cultura e nos media globais, sejam eles dominantes, populares, ou alternativos.

A CISL está a mudar. A dimensão e os limites dessa mudança ficaram bem patentes aquando do seu Congresso do Milénio, realizado em Durban, na África do Sul, no ano 2000 (v. South African Labour Bulletin, 2000). Reflectindo sobre o evento pouco tempo após a sua realização, Bill Jordan, Secretário Geral da CISL, afirmou:

[E]m períodos de mudança revolucionária, e é num período desses que nos encontramos hoje, temos que ser capazes de pensar e de agir para além da camisa de forças das nossas tradições... Mais uma vez o movimento sindical necessita de ideias novas para fazer face àquilo que são as novas necessidades de novos operários, novas profissões, novas formas de organização do trabalho, e novas relações de emprego. (Jordan, 2000)

O Congresso tomou, por isso, a decisão de submeter a organização a uma grande "exame do milénio", por forma a fazer frente aos desafios com que se vê confrontada. A verdade, contudo, é que não dispomos de qualquer indicação de que tal exame irá ser levado a cabo na presença sequer dos sindicatos seus filiados, e muito menos ainda com a participação dos membros desses sindicatos membros, nem após consultas com as organizações democrático-radicais e internacionalistas que a CISL anda, presentemente, a cortejar.

Os Secretariados Profissionais Internacionais (SPIs), são as mais antigas organizações sindicais internacionais, atravessando actualmente um processo de fusão, consolidação e redefinição. Tratarei aqui apenas daquele que melhor conheço e sobre o qual mais se tem escrito. A Federação Inter-

\footnotetext{
9 Kjeld Aagard Jakobsen (2001), Secretário para as Relações Internacionais da CUTB, principal confederação sindical de esquerda do Brasil, defende mesmo que tanto a CISL como a FSM se baseiam no modelo bolchevique! Em minha opinião, o referido modelo bolchevique não é senão uma adaptação do clássico modelo social-democrata alemão. Quanto à ideia de comparar/contrastar os modelos e o padrão de comportamento da CISL e da FSM, em vez de as estudar em termos de oposição, tem todo o aspecto de um projecto de doutoramento bonitinho.
} 
nacional dos Trabalhadores dos Transportes teve origem na vaga de protestos e de acções de mobilização dos trabalhadores deste sector que teve lugar especialmente na Europa da última década do século XIX e das três primeiras décadas do século Xx. ${ }^{10}$ Durante o período entre as duas Grandes Guerras constituiu uma parte significativa do internacionalismo sindical social-democrata que se opôs à ascensão do fascismo ao mesmo tempo que mantinha a distância relativamente à União Soviética. Além disso, a FITT afirmou-se por via da sua relação com a OIT, criada para resolver "o problema social” que sobreveio à I Guerra Mundial. Apesar de ter então passado a integrar os processos internacionais de negociação colectiva, a FITT continuou a apoiar a mobilização de massas e as acções de âmbito internacional na área da indústria. Além disso, produziu (ou abrigou) um dirigente sindical social-democrata de apreciável estatura histórica e de grande relevância para o seu tempo: Edo Fimmen ${ }^{11}$. A organização apoiou activamente os movimentos antifascistas e sindicatos clandestinos no interior dos Estados fascistas. Durante a II Guerra Mundial não só contribuiu de maneira significativa para o esforço de guerra antinazi desenvolvido pelo Reino Unido e pelos Estados Unidos como dele também recebeu apoio, descobrindo assim os benefícios da colaboração com os Estados democrático-liberais e com as respectivas actividades de espionagem. ${ }^{12} \mathrm{~A}$ cooperação da FITT com os serviços de informação dos EUA durante a II Guerra Mundial levou ao seu posterior envolvimento com a CIA durante a Guerra Fria e em particular à repressão violenta dos sindicatos dos trabalhadores portuários comunistas na França e na Itália, bem como à repressão ainda mais violenta do sindicalismo comunista e radical-nacionalista na América Latina e em África.

\footnotetext{
${ }^{10}$ Baseio-me aqui numa história colectiva da FITT, constante de um estudo da responsabilidade de Bob Reinalda (1997). V. ainda, no entanto, International Transportworkers Federation, 1996, e Couper, 1999. Para uma visão mais positiva do papel dos SPIs v., mais uma vez, Gallin (1999a). ${ }_{11}$ Deve-se a Fimmen um livro surgido nos anos 20 em que (algo prematuramente) se sustentava que o capitalismo europeu tinha tendência a unir-se, e que por esse motivo a ideia de uma confederação internacional de centros sindicais fazia menos sentido, perante as novas circunstâncias existentes, do que uma formada por SPIs (Fimmen, 1924)!

${ }^{12} \mathrm{Na}$ sua correspondência particular, Dan Gallin sugere que foi o inverso que aconteceu, quer dizer, que foram os Estados e os respectivos departamentos especializados quem descobriu que era necessário cooperar com os sindicatos e com os SPIs, e que, além disso, os sindicatos não tinham outra alternativa senão aceitar essa cooperação, caso desejassem ser eficazes na luta contra o fascismo. Pessoalmente, não tenho objecções a esta interpretação. Acho, porém, preocupantes as limitações e as implicações dessa cooperação secreta. Com efeito, ela veio criar um terreno de operações internacionais que conferiu aos sindicalistas com responsabilidades também internacionais um sentimento de que estavam a desempenhar um papel com uma importância histórica a uma escala mundial, mas sem a necessidade de participação alargada dos restantes membros ou qualquer conhecimento público.
} 
Durante o meio século que se seguiu a 1945, a FITT evoluiu no sentido de se transformar pelo menos num secundário "actor transnacional" no contexto do "sistema internacional" (Reinalda, 1997). Especialmente significativa, neste aspecto, é a prolongada campanha desenvolvida pela FITT relativa aos trabalhadores da marinha mercante subordinados às chamadas Bandeiras de Conveniência (BC), no que foi considerado um modelo de internacionalismo sindical num contexto de globalização. Os navios BC encontram-se registados fora da alçada das autoridades governamentais ou dos sindicatos nacionais, junto de Estados especialmente receptivos aos interesses dos grandes armadores, e as tripulações são contratadas ainda noutros países, a fim de assegurar uma mão-de-obra barata. Nestas circunstâncias, as acções concretas de carácter solidário têm muitas vezes partido de trabalhadores de fora desta indústria específica. A actividade da FITT no âmbito das BC implica o envolvimento da organização em negociações internacionais e traduz-se no estabelecimento de acordos colectivos também de âmbito internacional, incluindo um fundo para assistência social cobrado pelos armadores mas gerido pela FITT. Graças a essas acções, a FITT conseguiu não só recuperar milhões de dólares em salários atrasados devidos às tripulações, como também assegurar uma função de assistência adequadamente financiada. Hoje em dia, dezenas de inspectores portuários nomeados pela entidade sindical ou por ela aprovados acompanham e prestam apoio aos trabalhadores da marinha mercante por todo o mundo. Levanta-se, contudo, a questão de saber se o que aqui temos não será uma situação invertida, em que a FITT presta serviços reconhecidamente valiosos a uma mão-de-obra terceiro-mundista que não exerce qualquer controlo, directo ou sequer indirecto, sobre a entidade que a beneficia.

Historicamente, os trabalhadores portuários filiados na FITT desempenharam um papel importante de solidariedade com estes trabalhadores da marinha mercante claramente provenientes de outros países e outros sectores da indústria. Por outro lado, quando os trabalhadores portuários de Liverpool, também eles filiados na FITT, apelaram à solidariedade internacional no decurso da greve - uma greve heróica e desesperada, mas nem por isso menos inovadora - que em 1995-8 travaram contra um então triunfante neoliberalismo britânico, a FITT dispunha de pelo menos duas razões para lhes negar o seu apoio. A primeira é que eles eram, por assim dizer, súbditos de um determinado filiado nacional da FITT, o British Transport and General Workers Union, ele próprio relutante em apoiar plena e abertamente a greve. A segunda razão é que, dado o seu papel de agente interveniente na negociação colectiva em nome de tripulações internacio- 
nais das BCs, aquela organização encontrava-se registada como sindicato ao abrigo da legislação laboral anti-sindical britânica, estando por isso impedida de empreender as acções de solidariedade que lhe foram solicitadas sob pena de pôr em risco não só os fundos a seu cargo mas também as suas próprias sedes. Um dos inspectores portuários da FITT na cidade de São Francisco demitiu-se, num gesto de público protesto contra a política da organização relativamente à greve.

No que respeita à política de transportes internacionais, questão que desde há muito preocupa a FITT, parece que esta ainda

acredita num sistema de transportes racional, cooperativo, e publicamente planeado, objecto de um esforço de coordenação tanto nacional como internacional por forma a prestar um serviço eficiente e integrado de transporte de mercadorias e de passageiros. Dada a função social desempenhada pelos transportes, o seu planeamento deve prever a hipótese de benefícios e custos sociais mais amplos. A FITT considera que as actuais tendências internacionais no sentido da liberalização e da desregulamentação dos transportes constituem um passo atrás relativamente a uma tal concepção de serviço público. Há que ter o engenho necessário para encontrar um meio-caminho entre "os extremos que são uma indústria de transportes planificada e a sua completa liberalização”. (Reinalda, 1997: 31)

Esta política do meio-termo coloca a FITT lado a lado com os burocratas e os tecnocratas mais racionais e de mais largas vistas da cena internacional, ao mesmo tempo que aceita - e que efectivamente assume - os parâmetros do capitalismo. Tal facto, em si mesmo, é consentâneo com uma visão burocrática do internacionalismo enquanto relação existente não tanto entre trabalhadores como entre organizações sindicais nacionais. A circunstância de a FITT estar, efectivamente, a reconhecer os movimentos sociais ora emergentes parece também sugerir uma aliança com organizações não governamentais (ONGs) de âmbito nacional e internacional, em vez do estabelecimento de contactos directos entre trabalhadores e activistas de movimentos aliados. Se é certo que os SPIs hão-de continuar a existir, não há razões para pensar que se encontram devidamente apetrechados para enfrentar os novos tempos. São muitas as características que estas estruturas apresentam em comum com a CISL. E se ainda é possível detectar-lhes restos de alguma especificidade "industrial" tradicional, a verdade é que elas estão a ser objecto de uma rápida erosão devida às próprias alterações registadas na estrutura do capital e à vaga de fusões em curso nos SPIs, em grande parte motivadas por uma estratégia defensiva. Essas fusões só excepcionalmente lograrão responder de maneira 
satisfatória à esquiva geometria do capital, que com rapidez crescente muda, hoje em dia, de lugar, de produtos/serviços, de propriedade, e de formas de emprego. ${ }^{13}$

Estou convencido que tanto a CISL como a FITT virão forçosamente trazer elementos novos ao velho modelo de sindicalismo internacional. Quanto à FSM, é bem provável que não venha a ser mais do que um sério aviso daquilo que pode suceder quando não se é capaz de assumir a tradição, reconhecer as exigências do presente, e proceder à autoreformulação que se impõe para enfrentar o futuro. Se não quiser ficar para sempre refém do próprio passado, nostalgicamente procurando um regresso a um suposto período áureo de parceria entre a esfera do Trabalho, o Estado, e o Capital, o sindicalismo internacional terá seguramente de chegar a um entendimento do internacionalismo operário consentâneo com a desordem capitalista globalizada em que vivemos. ${ }^{14}$

\section{Como conceber um novo internacionalismo operário}

É cada vez mais frequente ouvir-se falar, tanto nos meios académicos como nos sindicais, de uma espécie de "sindicalismo de movimento social" com âmbito internacional ou global (Ashwin, 2000; Bezuidenhout, 1999; Moody, 1997). Ao mesmo tempo, contudo, existe uma estranha relutância em conceptualizar esta tendência (e, nesse aspecto, Munck, 2000, constitui, em parte, uma excepção). Vou, por isso - e também no propósito de provocar uma reacção crítica -, apresentar aqui três esboços de conceptualização inter-relacionados entre si e que se me afiguram relevantes para esta questão.

\footnotetext{
${ }^{13}$ Destes, o projecto mais ambicioso é talvez aquele que ostenta também a designação mais adequada: a Union Network International (UNI - Rede Internacional de Sindicatos), um SPI de "serviços e competências". No entanto, e como refere o próprio Congresso para um Mundo Aberto (Open World Conference, 2000a), esta organização não só parece convencida de poder fazer frente à vaga da globalização neoliberal como está efectivamente a construir um novo tipo de clientela e de gestão sindical por forma a transformar-se num interlocutor válido do capital globalizado e das instituições inter-estatais que o servem. É, assim, já possível fazer uma visita virtual ao Banco Mundial sem sair da sede virtual do sindicato.

${ }^{14}$ Há poucos indícios de que este novo entendimento esteja para breve. A CISL está actualmente identificada com o "Pacto Global" da ONU, um tentativa das Nações Unidas no sentido de cair nas boas graças do capital multinacional e de ao mesmo tempo lhe conferir uma aura ética. Intervindo a propósito do mundo do trabalho, Kofi Annan, presidente da ONU, "pediu” às gentes da área dos negócios a nível mundial que defendessem um conjunto de princípios de que se encontra excluída qualquer explicitação do direito à greve (ICFTU, 2000a, b). A CISL parece igualmente estar a ganhar as boas graças dessa grande potência mundial do futuro que é a China, não obstante a aversão deste país aos direitos dos trabalhadores e à independência dos sindicatos (China Labour Bulletin, 2000). Finalmente, a CISL e alguns SPIs estão também apostados na ideia de fixar uma "cláusula social" ou "padrões laborais" através da Organização Mundial do Comércio, apesar do crescente descrédito em que têm caído esta e outras instituições financeiras internacionais (Gumbrell-McCormick, 2000: 508-15; Waterman, 2001b).
} 
Um novo sindicalismo social. ${ }^{15}$ Entendo que um modelo deste tipo deverá ser um modelo capaz de superar os modelos de sindicalismo "económico", "político", ou "político-económico" actualmente existentes. Para tanto, é necessário que tenha em linha de conta todos os tipos de actividade laboral, que assuma formas socioculturais, e que esteja voltado para a sociedade civil. Um modelo sindical deste tipo deverá, além disso, apresentar, entre outras, as seguintes características:

- Deve centrar a sua luta na área do trabalho assalariado, combatendo não apenas por melhores salários e melhores condições mas também pelo aumento do controlo, por parte dos trabalhadores e dos sindicatos, do processo laboral e das políticas relacionadas com o investimento, a inovação tecnológica, a relocalização, a subcontratação, as políticas de educação e formação. Estas estratégias, bem como as lutas inerentes, deverão ser levadas a cabo em permanente diálogo e em acção combinada com as comunidades afectadas e tendo em conta os respectivos interesses, de maneira a evitar conflitos (por exemplo com grupos ambientalistas ou de mulheres) e a maximizar o poder mobilizador das reivindicações;

- Deve bater-se contra os métodos e as relações de trabalho de tipo hierárquico, autoritário e tecnocrático, a favor de produtos socialmente úteis e amigos do ambiente, assim como pela redução do horário de trabalho, pela distribuição do disponível e do necessário, pela partilha do trabalho doméstico, e pelo aumento do tempo livre com vista ao autodesenvolvimento cultural e à realização pessoal;

- Deve manter uma relação estreita com os movimentos de outras classes ou categorias não sindicalizadas ou não passíveis de sindicalização (o sector informal, os que trabalham a partir de casa, os agricultores, as donas-de-casa, os técnicos e as profissões liberais);

- Deve manter uma relação estreita com outros movimentos democráticos, de natureza não-classista ou multiclassista (como sejam movimentos de base associados à igreja, movimentos de mulheres, de moradores, de ambientalistas, de pacifistas, de direitos humanos, etc.), num esforço comum com vista à criação de uma sociedade vivil forte e diversificada;

- Deve manter uma relação estreita com outros (potenciais) aliados, sempre com o estatuto de parceiro autónomo, igual e democrático, não reivindicando para si-nem aceitando subordinar-se a - qualquer organização ou poder "de vanguarda" ou "soberano";

15 Deixo o conceito de "sindicalismo de movimento social", a que inicialmente fiz referência, para aqueles que, como veremos adiante, conferiram à expressão uma ampla projecção, ainda que traduzida em termos mais tradicionais ou "clássicos". 
- Deve fazer suas as novas causas sociais que forem surgindo na sociedade em geral, à medida que estas se forem colocando aos trabalhadores em particular ou se expressem no interior do sindicato (causas como a luta contra o autoritarismo, o majoritarismo, a burocracia, o sexismo, o racismo, etc.);

- Deve privilegiar a democracia no local de trabalho e promover as relações directas e de tipo horizontal, seja entre os trabalhadores propriamente ditos, seja entre estes e outras forças sociais democrático-populares;

- Deve mostrar-se activo na área da educação, da cultura e da comunicação, estimulando a cultura operária e popular, apoiando iniciativas tendentes a fortalecer a democracia e o pluralismo tanto dentro como fora das instituições ou dos media dominantes, seja no plano local, nacional ou global;

- Deve abrir-se ao funcionamento reticular intra- e inter-organizacional, dando mostras de compreender a importância que as associações, as alianças e os grupos de interesses, constituídos numa base informal, horizontal e flexível, podem ter para estimular a inovação, o pluralismo e a democracia organizacional.

Diversos autores, ao longo dos anos, têm identificado o "sindicalismo de movimento social” com 1) certas organizações nacionais específicas, 2) certas tendências sindicais de cariz militante ou de esquerda, e 3) o Sul ${ }^{16}$. Isto, em minha opinião, é errado não só do ponto de vista analítico como também do ponto de vista teórico e estratégico. Do ponto de vista analítico, tende a identificar como sendo "sindicatos do tipo movimento social" as

\footnotetext{
${ }^{16}$ Ao afirmá-lo tenho em mente, antes de mais, os textos de Lambert e Webster (1988) sobre a África do Sul do apartheid, Munck (1988: 117) sobre o Terceiro Mundo em geral, Seidman (1994: 2-3) sobre a África do Sul e o Brasil, e Scipes (1996: viii-ix) sobre as Filipinas. Munck (2000: 93-4) precisou um pouco mais a sua formulação, conferindo-lhe uma acepção mais lata. Quanto aos demais autores, nenhum propôs uma (re)formulação mais ampla do conceito. Extremamente influente, nos tempos mais recentes, é já a utilização que Moody faz do termo, no seu impressionante retrato da situação do mundo do trabalho à escala global (1997). Com efeito, o último capítulo desta obra intitula-se 'Para um Sindicalismo de Movimento Social com Âmbito Internacional'! No entanto, o relato que Moody nos oferece deste fenómeno não é mais que uma descrição/prescrição de um sindicalismo mais activista e democrático, ainda capaz de assumir o papel de direcção da classe operária na luta contra o neoliberalismo (290). Assim, embora apregoando um sindicalismo mais flexível, aberto e internacionalista, a proposta deste autor acha-se ainda tolhida pelos pressupostos obreiristas tradicionais. Seattle $(v$. abaixo) veio mostrar como, sob o capitalismo GCI, uma rede de movimentos sociais está em condições de assumir uma perspectiva mais abrangente e uma estratégia mais sofisticada e mais militante do que as que caracterizam os trabalhadores ou os próprios sindicatos isoladamente. Assim, a afirmação do papel de vanguarda da classe operária na luta contra o neoliberalismo pode revelar-se um gesto empiricamente errado e prescritivamente contraproducente.
} 
organizações sindicais envolvidas em diversos tipos de aliança popular-laboral, sobretudo em tempos de movimentações (semi-)insurreccionais contra regimes autoritários militares ou de direita. Do ponto de vista teórico, tende a reduzir uma categoria conceptual a analítica, impedindo desse modo que seja aplicada criticamente à evidência oferecida. Do ponto de vista estratégico, tende a tomá-la como característica de uma região específica do mundo - e isso numa altura em que a globalização homogeniza/diversifica o mundo de maneiras e formas que simultaneamente exigem e possibilitam a procura de alternativas universais (que não universalistas).

Um novo internacionalismo operário. Preocupado com os problemas do capitalismo GCI (de que as relações inter-estatais constituem apenas um aspecto), este modelo terá que ter consciência de que faz parte de um movimento de solidariedade global, com o qual tem a aprender e para o qual deve contribuir. Um novo tipo de internacionalismo operário implicará, entre outras coisas, o seguinte:

- Deve passar do plano das relações internacionais entre sindicatos ou funcionários sindicais para o plano das relações face-a-face entre as partes interessadas e directamente ligadas ao mundo laboral, seja ao nível do próprio local de trabalho, da comunidade, ou de outras organizações de base;

- Deve abandonar o modelo de organização internacional em forma de pirâmide - um modelo por demais centralizado, burocrático e rígido -, estimulando para tanto o modelo dinâmico, descentralizado, horizontal, democrático e flexível que caracteriza as redes de informação internacionais;

- Deve trocar o "modelo da ajuda" (fluxos unidireccionais de dinheiro e bens provindos de sindicatos, trabalhadores ou outras entidades "ricas, poderosas e livres") pelo "modelo da solidariedade" (fluxos bi- ou multidireccionais de apoio em termos políticos, de informação e de ideias);

- Deve passar das meras declarações de intenções, dos apelos públicos e dos congressos bem intencionados, para se traduzir em acções políticas, em trabalho criativo, em visitas ou ainda em contributos financeiros directos (que continuarão a revelar-se necessários) por parte dos trabalhadores interessados;

- Deve procurar que a solidariedade internacional seja praticada em função das carências quotidianas, das capacidades e dos valores expressos da população trabalhadora comum, e não apenas dos seus representantes;

- Deve reconhecer que embora a esfera do trabalho não seja o arauto privilegiado do internacionalismo, ele lhe é, no entanto, essencial, arti- 
culando-se por isso com outros internacionalismos democráticos por forma a reforçar as lutas pela melhoria de salários e a ir para além do mero internacionalismo obreirista;

- Deve ultrapassar a dependência ideológica, política e financeira da solidariedade internacional. Para tanto, deve procurar financiar as actividades internacionalistas com recurso a fundos públicos ou a contributos dos trabalhadores, e prosseguir actividades de investigação e uma orientação política independentes;

- Deve trocar os constrangimentos político-financeiros, os conluios privados e os silêncios públicos dos internacionalismos tradicionais por um discurso entre iguais que seja franco, amistoso, construtivo e público, além de acessível a todos os trabalhadores interessados;

- Deve reconhecer que não existe um lugar ou um nível exclusivo para o combate internacional, e que embora o ponto de partida para esse combate possa ser o local de trabalho, as organizações de base ou a comunidade, as instâncias formais de tipo tradicional podem ser igualmente utilizadas e, inclusivamente, influenciadas;

- Deve reconhecer que o desenvolvimento de um novo internacionalismo obriga a ir colher contributos aos movimentos de trabalhadores do Ocidente, do Leste, do Sul e de outras regiões sócio-geográficas, com os quais se impõe igualmente a constante troca de ideias.

É possível ver elementos deste modo de pensar tanto nas declarações como na prática das instâncias sindicais internacionais. Considero, de resto, que ele se está a transformar no senso-comum do internacionalismo operário de esquerda ( $v$., por exemplo, Lambert, 2001), apesar de haver ainda quem pareça achar que o internacionalismo operário (ou mesmo sindical) é quem lidera, ou devia liderar, a nova vaga de lutas contra a globalização neoliberal (Open World Conference, 2000a). Outros, no entanto, começam hoje a ir além desses tipos ideais, propondo alternativas globais - alternativas de carácter democrático e operário/popular - à "globalização-a-partir-de-cima", tanto em termos programáticos como em termos relacionais (Brecher et al., 2000).

Impõe-se uma última palavra no sentido de melhor clarificar e distinguir os conceitos de "internacionalismo", "internacionalismo operário", e "internacionalismo sindical". No discurso dos movimentos sociais, o internacionalismo é normalmente associado ao mundo operário do século XIX, ao socialismo e ao marxismo. Podemos, inclusivamente, fazê-lo recuar no tempo, por forma a abranger os antigos universalismos religiosos ou o cosmopolitanismo liberal do Iluminismo. E devemos fazê-lo avançar no tempo, de 
maneira a incluir formas como as lutas das mulheres/feministas, dos pacifistas, das forças anticoloniais, e em prol dos direitos humanos. Dado tratar-se destes dois últimos séculos, e de um "mundo de Estados-nação", precisamos de uma palavra nova para referir a era da globalização. Alguns autores falam de transnacionalismo. Eu prefiro a expressão solidariedade global, por traduzir não apenas a globalização mas também o mal-estar que provoca e as alternativas que se nos colocam. Quanto ao internacionalismo operário, refere um vasto leque de ideias, estratégias e práticas, passadas e presentes, relacionadas com a realidade da esfera do trabalho, e que vão desde a actividade das cooperativas e dos partidos operários e socialistas até ao papel dos intelectuais socialistas e à cultura, passando pelos meios de comunicação e, inclusivamente, pelo desporto. Quanto ao internacionalismo sindical, restringe-se à forma preferencial de auto-articulação dos trabalhadores (quer dizer, de auto-organização e auto-expressão) durante o período NIC. Na parte final do século Xx, o internacionalismo sindical desalojou ou sobrepujou o internacionalismo operário a tal ponto que os dois termos acabaram, em grande parte, por se tornar sinónimos. Contudo, nesta nossa era de capitalismo GCI é precisamente o internacionalismo sindical que se encontra mais em crise e que mais é posto em causa.

$\mathrm{Na}$ secção que se segue irei debruçar-me - à luz do que atrás ficou exposto - sobre os modos como a esfera do trabalho a nível internacional, ou o internacionalismo operário, está ou não a conseguir dar resposta aos novos movimentos de solidariedade global. Mais uma vez, a análise continuará a centrar-se nas instituições sindicais internacionais de tipo tradicional, bem como na questão das formas e dos procedimentos.

\section{O Diálogo do Milénio sobre a Esfera do Trabalho a Nível Internacional}

"Diálogo do Milénio sobre a Esfera do Trabalho a Nível Internacional" é o nome que dou a algo que existe no plano empírico e que me proponho aprofundar no plano programático. No período 1999-2000 assistimos a um número crescente de diálogos sobre a esfera do trabalho e a globalização, quer entre os sindicatos, quer entre os trabalhadores propriamente ditos, quer ainda entre as forças socialistas ou no meio académico. Torna-se evidente que tais diálogos foram estimulados pela circunstância de o final do milénio ter coincidido com aquilo a que chamamos "crise da globalização". Esta expressão, por sua vez, designa não apenas a crise que a esfera do trabalho atravessa mas também a que caracteriza o próprio projecto da globalização neoliberal enquanto tal. Entre os congressos que sobre o tema tiveram lugar, é de salientar, antes de mais, essa grande iniciativa internacional que foi a Conference on Organised Labour in the 21st Century 
(COL21 - Congresso sobre Organização Sindical no Século XXI; $v$. Websites, no final). Promovido pela CISL e pela OIT nos anos de 1999-2000, foi um congresso electrónico de carácter aberto e bilingue. Por outro lado, tenho conhecimento, sobretudo nesse mesmo período de 1999-2000, de nove ou dez outras realizações internacionais relacionadas com o mundo do trabalho e centradas na temática neoliberalismo/globalização. Neste caso, tratou-se de iniciativas quase sempre periféricas - ou transversais, ou exteriores - às estruturas sindicais internacionais de tipo tradicional.

COL21: diálogo de qual milénio? Não obstante o formato electrónico, a possibilidade de acesso internacional, e o carácter aparentemente aberto, trata-se de facto de um diálogo em larga medida espartilhado pela própria história dos seus dois patrocinadores e pelo interesse de ambos em preservar ou restaurar a centralidade que já detiveram no panorama das relações laborais internacionais. Com uma excepção apenas - a de Richard Hyman (1999a), especialista de esquerda em assuntos do trabalho -, as declarações introdutórias tanto dos convidados como dos patrocinadores institucionais ativeram-se aos tradicionais parâmetros discursivos das "relações industriais", da "parceria social" e do "desenvolvimento". Outras palavras-chave, como por exemplo a "solidariedade internacional", a "CISL" e a "OIT" - sem dúvida fulcrais, todas elas, para o futuro do trabalho sindical organizado -, não foram objecto de discussão, e muito menos de questionação. Numa primeira análise do que se passou no COL21, diria que da lista dos participantes constavam os suspeitos do costume: indivíduos de raça branca, de proveniência anglo-saxónica, e do sexo masculino (o mesmo se passando inicialmente com os proponentes da agenda, se se exceptuar o caso do chileno Juan Somavia, Director Geral da OIT). A maioria das comunicações de fundo feitas a solicitação da OIT limitaram-se ao tópico os-sindicatos-e-a-globalização-no-meu-país. Não obstante os contributos plenos de informação, e a ocasional assunção de posições críticas por parte de algumas intervenções, foi pouca ou nenhuma a reacção às declarações de abertura, além de não se notar que houvesse diálogo entre os participantes. Aquando do lançamento do sítio de língua espanhola na "Web", a maior parte das mensagens foi de cumprimentos. Se posteriormente este mesmo sítio ganhou mais vida, foi provavelmente por ter passado a contar com uma responsável mais dinâmica. ${ }^{17}$ Além disso, alguma indagação posteriormente levada a

\footnotetext{
${ }^{17}$ Apesar das diversas tentativas que fiz para fazer chegar ao COL21 mensagens de diferentes tipos e de extensão variável, e apesar ainda das diversas promessas de que uma delas seria divulgada, levou quase um ano até que tal sucedesse efectivamente - se bem que no sítio espanhol da "Web", e em inglês!
} 
cabo a título pessoal, tanto nas Américas como na Europa Ocidental, é de molde a sugerir que os especialistas em assuntos do trabalho a nível internacional, e nomeadamente os de orientação mais crítica, não se manifestaram particularmente interessados em participar nesta experiência, ainda que o possam ter feito com o estatuto de observadores mudos (isto é, através de uma participação passiva). Nada disto, porém, significa que a experiência deve ser desprezada. Pelo contrário, a presente crítica deve ser entendida como uma provocação no sentido de que se empreenda uma investigação sistemática sobre o COL21, incluindo o respectivo patrocínio e gestão, os temas tratados, os discursos, a participação e o impacto, e ainda as semelhanças/diferenças entre o sítio inglês e o espanhol. A questão fundamental, em suma, é que (e aqui atrevo-me a falar também pelo leitor) necessitamos urgentemente de um sítio de discussão desse tipo, pois que na verdade ele ainda não existe. ${ }^{18}$

\section{Os congressos não-oficiais: que diálogo do milénio? Aos sete congressos a} que atrás aludi há que acrescentar um importante precedente, realizado em 1988, e dois outros eventos surgidos já numa fase mais tardia, no final de $2000 .{ }^{19}$ Estas iniciativas têm vindo a ter lugar nas margens - ou nas bases institucionais, políticas, educativas e académicas das estruturas sindicais

\footnotetext{
${ }_{18}$ Uma possível excepção será a Labor-List, de San Lanfranco ( $v$. Websites, no final), onde já houve lugar a uma ou duas discussões aprofundadas sobre certos temas relacionados com o mundo do trabalho a nível internacional. Fica-me, no entanto, a impressão de que os participantes desta lista de discussão ou não estão interessados em debater as questões relacionadas com as organizações e as instituições internacionais, ou sentem-se pouco preparados para o fazer.

${ }_{19}$ Segue-se a lista destas iniciativas, de que se fornecem as respectivas fontes, quando disponíveis, no final do presente artigo:

- Um evento "pré-milénio", patrocinado em 1998 pelo Sindicato Geral dos Trabalhadores Dinamarqueses por ocasião de um aniversário e subordinado ao tema Uma Nova Agenda Global: Perspectivas e Estratégias para o Século XXI;

- Uma iniciativa realizada no Brasil, em Setembro de 1999, sob o patrocínio de sindicatos e com o título Encontro Mundial Contra a Globalização e o Neoliberalismo;

- Uma iniciativa trotskysta intitulada Congresso para um Mundo Aberto em Defesa dos Direitos Democráticos e da Independência dos Sindicatos, realizada na cidade de São Francisco, em Fevereiro de 2000;

- Uma iniciativa de âmbito nacional e carácter sindical/académico/formativo, realizada em Milwaukee, Wisconsin, em Abril de 2000 sob a designação Os Sindicatos e a Economia Global: A Encruzilhada da Formação Sindical;

- A segunda edição de um festival/congresso internacional sobre a esfera do trabalho e os media electrónicos na era da globalização, intitulado LabourMedia99 e realizado em Seul, em Novembro de 1999;

- Um congresso sobre O Sindicalismo no Século XXI, organizado em Joanesburgo, em Outubro de 1999, pela Iniciativa do Sul sobre a Globalização e os Direitos Sindicais (SIGTUR);

- Um congresso internacional com o título Construir um Movimento Sindical para uma Mudança Radical, organizado em Colónia, na Alemanha, em Março de 2000, por iniciativa de uma entidade
} 
internacionais. A maioria teve lugar em países tradicionalmente do centro do capitalismo, mas em vários casos (Coreia, África do Sul, México, Brasil) não foi assim. Além disso, na maior parte dos casos em que as realizações tiveram lugar nos EUA, e tanto quanto é do meu conhecimento, houve participação de membros de países do Sul, só excepcionalmente havendo participantes dos antigos países comunistas.

Já tive oportunidade, noutro local, de comentar um congresso/rede deste tipo (Waterman, 1999a), pelo que de momento me limitarei ao Congresso para um Mundo Aberto em Defesa dos Direitos Democráticos e da Independência dos Sindicatos (CMA), realizado na cidade de São Francisco entre 11 e 14 de Fevereiro de 2000 (OWC - Open World Conference, 2000b). Foi este, muito provavelmente, o maior de todos os eventos de carácter informal, com 560 participantes provenientes de 56 países, 200 dos quais de fora da América do Norte. Tratou-se de uma iniciativa trotskysta com intervenções a cargo dos dirigentes do partido organizador, mas onde esta dimensão esteve atenuada e que conseguiu envolver pessoas situadas fora da esquerda tradicional. Além disso, foi inteiramente financiada por sindicatos e por organizações ligadas a movimentos comunitários e laborais, o que permitiu reunir a soma de 11 a 14 mil dólares necessária à realização do evento. Foram nove os painéis realizados, dedicados aos mais variados tópicos: mulheres trabalhadoras, trabalhadores imigrantes, privatização e desregulamentação, sociedade civil e ONGs, paz e autodeterminação, racismo e direitos democráticos, integração dos sindicatos nas estruturas empresariais e/ou estatais (a todos os níveis), o mundo do trabalho e o ambiente. Além disso, o congresso debruçou-se atentamente sobre a ONU e a OIT, considerando que tanto uma como outra têm vindo a abandonar o papel que tradicionalmente lhes cabe e a deixar-se assimilar, numa posição subordinada, no projecto de globaliza-

\footnotetext{
baseada em Amesterdão, a Transnationals Information Exchange, e que entre os seus principais tópicos contou com o tema "Um Novo Internacionalismo?";

- Um seminário sobre O Actual Panorama das Estruturas Sindicais Internacionais: Novos Desafios e Estratégias Sindicais em Face da Globalização, organizado na Cidade do México em Novembro de 1999 e com contributos estrangeiros/internacionais. Apesar de dirigido a um público nacional, este seminário partilhou das preocupações e orientações das iniciativas atrás mencionadas;

- Um "Workshop" sobre os Direitos Internacionais dos Trabalhadores e a Solidariedade Operária Internacional, realizada no Wellesley College, na região de Boston, EUA, em Novembro de 2000 com o objectivo de propiciar a troca aprofundada de opiniões entre especialistas das universidades, dos sindicatos e das ONGs e incluindo participantes da Ásia, da América Latina e de outras partes do mundo;

- LaborTECH 2000: Para Construir um Novo Sindicalismo Global através dos Media, Universidade de Wisconsin, Madison, EUA, 1 a 3 de Dezembro de 2000. O último de uma série de eventos deste tipo com alcance internacional e um índice de participação significativo.
} 
ção neoliberal (Sandri, 1999). Tratou-se, em suma, de uma iniciativa notável e até heróica, reveladora da capacidade de um partido socialista de vanguarda de tipo tradicional para enfrentar a globalização neoliberal de uma maneira enérgica, ampla e com dimensão internacional. A acrescentar a esse facto, ficou demonstrado que há organizações representativas de centenas de milhares de membros dispostas a responder a um apelo deste género. Finalmente, o CMA viria ainda a criar o seu próprio sítio e a produzir um vídeo e relatórios impressos sobre os trabalhos $(v$. Vídeos, no final), encontrando-se muitos destes materiais traduzidos para outras línguas.

Quero, no entanto, levantar algumas questões sobre certos aspectos deste evento, alguns deles comuns aos outros congressos "alternativos" já mencionados, outros semelhantes ao próprio congresso da CISL. O primeiro é o carácter defensivo de que se revestiu, e desde logo a partir do título. A linguagem utilizada é a linguagem da resistência militante: "denunciar", "preservar", "desviarmo-nos das (...) tentativas de cooptar", "responder aos ataques", "lutar contra", "defender", "travar", "re-nacionalizar", "recusar". Não se vislumbra aqui qualquer sinal da passagem (para usar a terminologia feminista da América Latina) "da oposição à proposição". O segundo aspecto é o pressuposto de que a classe trabalhadora é a vítima principal do neoliberalismo. A expressão "classe trabalhadora" é, assim, alargada por forma a abarcar todos os pobres (mulheres, agricultores, povos indígenas, residentes urbanos), negando-se deste modo a estes qualquer outro interesse ou identidade significativos para além dos de trabalhadores pertencentes ao sexo masculino, a sindicatos e ao mundo urbano. Daqui decorre o terceiro aspecto, que é o pressuposto segundo o qual o movimento sindical inter/nacional é, ou deverá ser, a força dirigente necessária para proceder à inversão (sic) do neoliberalismo. E o pressuposto de que todas as instituições não-tradicionais - sejam as "ONGs", a "sociedade civil", "a chamada globalização", e mesmo as fusões de sindicatos a nível nacional ou internacional - são, objectivamente, instrumentos do inimigo de classe, e que só vêm enfraquecer ou confundir a luta de classes (isto é tanto mais paradoxal quanto o CMA, ou a força que lhe subjaz, o International Liaison Committee - Comité de Ligação Internacional, CLI -, é, ele próprio, uma ONG). Um sexto aspecto a referir são as lacunas importantes. Apesar de haver uma sessão sobre/de mulheres, a única reivindicação do congresso neste domínio teve a ver com um mecanismo da OIT relativo às licenças de parto; não foi feita qualquer menção ao assédio sexual e aos direitos que lhe estão associados, nada sendo dito portanto também a respeito da 
questão do patriarcado no interior tanto do movimento sindical inter/ nacional como do próprio CLI/CMA. E apesar de ter havido uma proposta feita por uma mulher no sentido da criação de um comité internacional de mulheres operárias, a ser dirigido por mulheres, não saiu dos trabalhos qualquer referência ao feminismo, não obstante este ser sem dúvida a principal força teórica e ideológica a conferir forma e impulso às lutas das mulheres trabalhadoras a nível internacional ao longo dos últimos 20 anos. Não se ouviu - e é este o sétimo aspecto que pretendo referir - qualquer crítica ao sindicalismo internacional de tipo tradicional propriamente dito. ${ }^{20}$ Finalmente, e em conformidade com isto, não houve nenhum painel nem nenhuma declaração - e muito menos houve qualquer discussão - sobre o significado do internacionalismo, seja no passado ou no presente, seja ao nível dos sindicatos, da esfera do trabalho, do movimento socialista, ou a nível mais geral. O congresso foi, em resumo, marcado não só por uma atitude de radical oposicionismo como também pela ideologia do obreirismo/classismo. O internacionalismo que lá houve foi em grande parte, e por defeito, o do período NIC.

Atrevo-me a fazer uma generalização - ou, se se preferir: a avançar com uma proposição - respeitante às realizações de tipo informal: por norma elas têm os pés assentes na nova terra da globalização neoliberal, mas muitas vezes têm a cabeça no mundo das velhas ideologias e instituições. Isto deve, obviamente, entender-se como uma crítica, mas deve ser também uma constatação. A maioria destes eventos, apesar de frequentemente inovadores, tem nos respectivos organizadores $e$ participantes pessoas que ainda parecem sentir-se mais à vontade com os discursos do imperialismo ou do nacional-proteccionismo; que continuam agarradas à ideia de que as estruturas sindicais (e/ou o partido trabalhista/socialista) são as principais ou as únicas instituições a ter em conta na luta contra a globalização; que concebem o internacionalismo em termos de relações entre sindicatos nacionais, locais, ligados à indústria, ou baseados na realidade da empresa; e que entendem o diálogo internacional como uma "troca de experiências", e o plano nacional, as mais das vezes, como terreno privilegiado ou exclusivo da resistência e da reafirmação. As próprias metodologias - não obstante, por vezes, as intenções em contrário - tendem a reproduzir as práticas que tradicionalmente caracterizam a actividade sindical e partidária. Alguns des-

\footnotetext{
${ }^{20}$ As críticas ao sindicalismo internacional que se fizeram ouvir dirigiram-se às novas formas por este assumidas, e particularmente à já referida Rede Internacional de Sindicatos. Embora houvesse críticas à central norte-americana $\mathrm{AFL} / \mathrm{CIO}$, nomeadamente em conexão com Seattle, o $\mathrm{CLI} / \mathrm{CMA}$ deve ter-se sentido pouco à vontade para criticar organizações às quais os participantes deviam lealdade.
} 
tes projectos ainda consideram que são a voz privilegiada do novo internacionalismo operário (o congresso da vanguarda? A rede da vanguarda?). E mesmo quando não têm tais pretensões, não parecem dar-se conta ou ter consciência da existência dos demais, ainda que com eles coincidam no objecto da reflexão e nos propósitos, e inclusivamente quando alguns dos seus participantes marcam presença em uma ou mais iniciativas das outras. Tudo isto não só pode como provavelmente deve ser entendido como um sinal 1) da novidade que são as redes e a conectividade reticular, e 2) da persistência do choque trazido pela globalização, numa altura em que os activistas inter/nacionalistas militantes lançam mão de ferramentas velhas no seu esforço para desalojar um capitalismo radicalmente transformado e que por isso mesmo (tal como acima se indica) exige ferramentas radicalmente transformadas também.

Tudo isto, a meu ver, são razões suficientes para não se equacionar as referidas iniciativas informais em oposição ao COL21, ou mesmo às Conferências do Milénio organizadas pela CISL. Talvez que em certos aspectos, em determinados domínios e nalguns dos temas tratados, a CISL esteja à frente do CMA (como por exemplo na questão das mulheres e nas relações com as ONGs). Considero, por isso, que devemos antes encarar todos estes congressos como um espaço internacional novo e uno, uma ágora (uma espécie de praça pública, lugar simultaneamente de encontro e de troca) de que se impõe fazer o novo mapa e de que está ainda por traçar o quadro completo.

\section{Comunicações, cultura e computadores: do espaço ao ciberespaço?}

A necessidade de conferir uma forma comunicacional/cultural e electrónica à esfera do trabalho e à sua faceta internacionalista tornou-se agudamente patente por ocasião da "Batalha de Seattle" contra a Organização Mundial do Comércio nos finais de 1999. A iniciativa de realizar a manifestação partiu de uma rede de ONGs - ou, melhor dizendo, de uma rede de redes de ONGs. Houve uma participação significativa de representantes do mundo do trabalho a nível internacional, incluindo dos EUA, mas tanto quanto sei nem uns nem outros desempenharam qualquer papel na condução deste acontecimento ou na definição da sua natureza. De facto, o que se passou foi exactamente o inverso. Os participantes e os observadores internacionais ligados a estruturas sindicais mantiveram-se, por norma, afastados das partes do evento em que não participavam ou que não controlavam. A mobilização a nível internacional foi levada a cabo, em grande parte, através da Internet. As acções de protesto estiveram em larga medida a cargo da Direct Action Network (Rede de Acção Directa), 
com quem as pessoas receberam treino em formas de acção flexíveis e articuladas. Naomi Klein (2000) descreveu do seguinte modo toda a novidade e riqueza deste multifacetado evento:

\begin{abstract}
Não obstante (...) a sua base comum, estas campanhas não confluiram no sentido de um movimento único. Pelo contrário, interligam-se de uma maneira estreita e intrincada, como os próprios "hotlinks" que asseguram a ligação das páginas que têm na Internet. Esta analogia não é feita por acaso: a tecnologia comunicacional que torna estas campanhas possíveis e eficazes está a moldar o movimento à sua própria imagem. Graças à "Net”, as mobilizações desenrolam-se com recurso a uma burocracia escassa e uma estrutura hierárquica mínima; os consensos forçados e os manifestos longamente negociados vão, assim, ficando para trás, dando lugar a uma cultura de constante troca de informações, marcada por uma prática fluida e por vezes compulsiva (...) O carácter descentralizado destas campanhas não é fonte de incoerência e de fragmentação mas sim uma adaptação razoável e até engenhosa às mudanças verificadas no panorama da cultura em sentido geral. (23-4. Sublinhado meu. PW)
\end{abstract}

Contribuindo com cerca de $50 \%$ dos participantes, os sindicatos dos EUA tiveram um envolvimento tardio, organizaram actividades à parte (num estádio e num salão) e procuraram encaminhar a sua marcha para longe dos locais onde a polícia enfrentava com brutalidade a resistência dos manifestantes não violentos (que não deve ser confundida com a pequena minoria que entretanto se lançava sobre as multinacionais em High Street). Os sindicatos internacionais estiveram ausentes dos media dominantes, embora a sua visibilidade seja pouco maior nos vídeos alternativos feitos sobre o evento ( $v$. Vídeos). Alguns dirigentes sindicais nacionais e internacionais ignoraram ou inclusivamente repudiaram a cautelosa política e a estratégia da AFL-CIO. Alguns dos maiores sindicatos dos EUA, bem como inúmeros sindicalistas, pura e simplesmente romperam as fileiras e juntaram-se ao resto dos manifestantes. Mas enquanto os ecologistas apareceram vestidos de tartarugas, os sindicalistas apareceram vestidos de... sindicalistas. E enquanto os sindicalistas não-violentos expressavam a sua resistência correndo risco físico, os dirigentes dos EUA ajoelhavam durante alguns momentos, em atitude de oração. ${ }^{21}$ Resultado: esses $50 \%$ de sindicalistas tiveram direito a $5 \%$ de cobertura com imagem nos principais noticiários internacionais (que o mesmo é dizer, dos EUA)! Só se poderia atri-

\footnotetext{
${ }^{21}$ Deixarei aos observadores americanos a tarefa de explicar as origens históricas exactas e o significado cultural daquilo que para mim constituiu um ritual estranho e até exótico.
} 
buir este facto a um "tendenciosismo dos media" se as formas de expressão utilizadas tivessem sido tão originais, apelativas, aparatosas ou lúdicas como as dos demais manifestantes.

Tirando algumas excepções assinaláveis, o movimento operário internacional ainda não compreendeu o significado de tudo isto. Jean-Paul Marthoz (2000), jornalista desde há muito ligado à CISL, reconhece a centralidade crescente dos media no contexto do processo de globalização bem como o potencial que tanto os media como os seus trabalhadores encerram na luta contra a globalização. Contudo, em face da cobertura mediática que os grupos e as atitudes radicais tiveram em Seattle, este autor considera que a projecção pública conferida aos acontecimentos que ali tiveram lugar é razão "mais para cautela do que para euforia". E porque não ambas? E porque é que - para voltar ao tema dos sindicatos e dos media - a esfera do trabalho a nível internacional não surge identificada nem associada de uma forma significativa com o novo movimento internacional para a democratização das comunicações (Voices 21)? Tudo indica que mais uma vez o mundo do trabalho a nível internacional se prepara para responder à nova esfera pública globalizada e às novas formas de expressão colectiva em modo defensivo/agressivo, quando o devia fazer em termos de aprendizagem/ criatividade.

Há muito já que é possível detectar, nas atitudes do sindicalismo internacional relativamente às novas tecnologias da informação e da comunicação (TIC), este tipo de reacção verdadeiramente conservadora. Tal sentimento começou a fazer-se notar há quase 20 anos, quando a CISL recusou a oferta, por parte de um especialista de informática social-democrata da Escandinávia, de uma base de dados de livre acesso chamada - ironicamente, dadas as circunstâncias - Unite. ${ }^{22}$ Hoje em dia a atitude mantém-se, assistindo-se àquilo que poderíamos chamar uma desastrada tentativa, por parte da CISL, de criar e controlar na Internet um domínio sob a designação "sindicato" (isto é, "union", a exemplo de designações já existentes como por exemplo.com, .uk, ou .org). ${ }^{23}$ É com agrado que se assiste ao aumento,

22 A proposta em causa foi mesmo promovida publicamente no interior da CISL por Ian Graham (1982a, b), então editor responsável pela então chamada Free Labor World. Posteriormente Graham passar-se-ia para a International Chemical, Energy and Mineworkers Federation (ICEM - Federação Internacional dos Trabalhadores do Sector Químico, da Energia e das Minas), uma organização bastante mais sensibilizada para o papel das comunicações e da informática.

${ }^{23}$ Foi essa a conclusão a que cheguei com base numa exposição sobre o assunto feita por Eric Lee (2000). A CISL caracterizou-se, neste caso, por um pensamento burocrático, tecnocrático e territorialista. Burocrático na medida em que 1) visava uma relação exclusiva entre órgãos ou funcionários de um determinado aparelho (sendo a outra parte a comissão - dominada pelo mundo empresarial - incumbida da distribuição de nomes de domínios na Internet) e porque 2) até ao 
na "Web", do número de sítios de estruturas sindicais internacionais a oferecer um acesso cada vez maior à informação sobre as actividades que desenvolvem. Mas isso não passa de uma resposta atrasada àquilo que são as virtualidades das TIC enquanto instrumento (mais rápido, mais barato e de maior alcance), não enquanto ciberespaço (quer dizer, um outro tipo de espaço, com possibilidades ilimitadas no que se refere ao diálogo internacional, à criatividade e à invenção/descoberta/desenvolvimento de novos valores, de novas atitudes e de novos diálogos). Assim, até mesmo esse novo e admirável sítio multi-sindical que é o Global Unions não é mais que um serviço - um serviço do tipo magazine e de informação, e eventualmente também de mobilização - maior, mais rápido e de maior alcance. ${ }^{24}$ Trata-se, por conseguinte, primordialmente de órgãos de propaganda, ${ }^{25}$ que só ocasionalmente poderão servir para criar as práticas e os entendimentos dialécticos necessários a esta nossa nova realidade capitalista, tão complexa e globalizada.

Para encontrar práticas mais adequadas ao novo clima da globalização, temos de procurá-las em meios de comunicação de tipo mais marginal: por exemplo revistas como a International Trade Union Rights ("Direitos Sindicais Internacionais", que publicou um extenso debate sobre a problemática questão dos direitos e comércio internacionais); sítios da responsabilidade de ONGs e/ou de particulares, como o serviço noticioso (e não só) Labourstart, de Eric Lee; ou ainda as propostas provocatórias de novos princípios de organização sindical apresentadas por Richard Barbrook, um homem de esquerda especializado na área das comunicações. Barbrook

momento não foi objecto de publicitação, nem de consultas com especialistas exteriores aos sindicatos, nem de mobilização dos membros da CISL, nem sequer de consultas junto do público interessado. Tecnocrático por acreditar que existe um remédio de natureza técnica para os problemas dos direitos democráticos relacionados com o mundo do trabalho. E territorialista porque a ideia era que fosse a CISL e os respectivos sindicatos membros ou aliados a decidir quais os sindicatos que são "autênticos", com direito, portanto, à utilização do nome do domínio. A própria noção de criar um espaço territorial no ciberespaço sugere, enfim, uma falta de compreensão do que este último seja. Lee aponta todo um conjunto de modos como é possível marcar uma presença sindical ao nível do ciberespeço e de achar na "Net" materiais com relevância para as questões do trabalho sem precisar de recorrer à criação de um novo domínio. Ademais, essas modalidades afiguram-se acessíveis a todo e qualquer activista interessado, que para tanto só necessita, além do próprio interesse pelas questões da solidariedade internacional, de se munir de imaginação e das técnicas básicas para navegar na "Web".

${ }^{24}$ Nem mesmo a melhor de todas as novas revistas sindicais impressas e de âmbito internacional, a Metal World, da International Metalworkers Federation (IMF - Federação Internacional dos Metalúrgicos, FIM), dispõe de uma secção de cartas dos leitores, e muito menos ainda de um espaço aberto para o debate mais alargado. Compare-se essa lacuna com as duas páginas (em 16) facultadas pela Labor Notes, publicação internacionalista produzida nos EUA.

${ }^{25}$ Veja-se a definição do termo dada pelo Shorter Oxford English Dictionary: "disseminar, difundir (uma declaração, crença, ou prática)". 
concebe as TIC, não como algo que os trabalhadores ou os sindicatos se limitam a usar, mas como algo que estes produzem e que por seu turno produz trabalhadores e, mais do que isso, trabalhadores carecidos de sindicatos de um outro tipo:

A exemplo do que sucede nas outras indústrias, os trabalhadores da economia digital emergente necessitam de defender os seus interesses comuns. A maioria das organizações de trabalhadores existentes, porém, não está a conseguir dar uma resposta suficientemente rápida às mudanças verificadas nas vidas de quem trabalha. Apesar de criados para dar luta aos patrões, os sindicatos da indústria foram também criados à imagem da fábrica fordista: burocrática, centralizada e nacionalista. Para quem trabalha na economia digital, este tipo de organização tem muito de anacrónico. É, pois, necessário que em seu lugar sejam criadas novas formas de sindicalismo, capazes de representar os interesses do trabalhadores do sector digital. Para além da reforma das organizações sindicais existentes, é altura de estes trabalhadores começarem também a cooperar uns com os outros servindo-se dos métodos que lhes são próprios. Dado que já se encontram em linha, deveriam organizar-se no sentido de promover os seus interesses comuns através da Net. Um sindicato virtual assim constituído, a funcionar no interior da economia digital, deveria ainda pôr uma grande ênfase nos novos princípios de organização do trabalho: uma ênfase no artesanal, no reticular, e no global. (Barbrook, 1999)

Para uma compreensão ainda mais geral do papel das TIC relativamente ao internacionalismo, proponho que novamente olhemos para além da perspectiva específica da esfera do trabalho, detendo-nos por momentos sobre o tema "Mulheres@Internet":

As redes - redes de mulheres, ambientalistas, étnicas, e de outros movimentos sociais - são um espaço de novos actores políticos e uma fonte de práticas culturais extremamente prometedoras. É, por isso, possível falar de uma política cultural do ciberespaço e da produção de culturas capazes de opor resistência, de causar transformações, ou de apresentar alternativas aos mundos virtual e real dominantes. Uma tal política cibercultural poderá ser especialmente eficaz se preencher duas condições: deve ter consciência dos mundos dominantes actualmente em vias de criação pelas mesmas tecnologias em que as redes progressistas se baseiam (incluindo a consciência do modo como o poder funciona no mundo das redes e dos fluxos transnacionais); e deve fazer o vaivém constante entre a ciberpolítica (ou seja, o activismo político na Internet) e aquilo que designo por política do lugar, quer dizer, o activismo político praticado nos espaços físicos em que o utente da Net utiliza este meio e faz a sua vida. (Escobar, 1999: 32) 


\section{Conclusão: conectividade reticular, comunicação, diálogo}

Aventei atrás a ideia de que o problema fundamental do internacionalismo sindical no contexto do capitalismo GCI se prende com as formas e as práticas, sendo que as formas e as práticas do sindicato são fortemente marcadas pelo capitalismo NIC dentro do qual - e em relação ao qual - ele tomou forma. Isso quer dizer que a crítica da burocracia, da estrutura hierárquica e da ideologia sindical (proverbial fonte de queixas por parte da esquerda tradicional) é um tanto descabida, para não dizer deslocada no tempo. Faz-nos, de facto, falta um princípio de auto-articulação novo ou mesmo alternativo, quer dizer, um meio que sirva simultaneamente de auto-organização e auto-expressão dos trabalhadores, mas sobretudo que seja verdadeiramente adequado ao nosso tempo. (Faz falta, por outras palavras, um princípio que contrarie de uma maneira permanente e eficaz a reprodução da ideologia e da estrutura burocrático-hierárquica, a qual não deixa de ter lugar também no interior dos sindicatos "radicais" e "revolucionários").

Como transparece das duas últimas citações, esse princípio é a rede, sendo a prática a conectividade reticular. Não há que feiticizar a rede ou diabolizar a organização. A "conectividade reticular" é também uma forma de entender as inter-relações humanas, pelo que podemos encarar uma organização em termos de rede, tal como podemos olhar para uma rede em termos organizacionais. Não deixa, contudo, de ser verdade que a passagem do capitalismo NIC para o capitalismo GCI é também a passagem de um capitalismo organizado para um capitalismo reticular (Castells, 1996-8). É das redes e da conectividade reticular internacionais ligadas ao mundo do trabalho que hoje em dia tendem a surgir as novas iniciativas, traduzidas em factores como a velocidade, a criatividade e a flexibilidade. Quando os sindicatos, ou as forças socialistas, condenam ou simplesmente criticam as ONGs por falta de "democracia" ou de "representatividade", mostram com isso que não compreendem os novos princípios, formas e práticas dos movimentos sociais democrático-radicais. Estes têm por preocupação essencial a capacitação através da informação, de ideias, de imagens, de son et lumière, de valores. Quando falamos de uma conectividade reticular, ou de redes - ou de ONGs - democrático-radicais, há que ter em mente que estas representam uma grande fonte de renovação e de movimento, seja no seio da sociedade civil, com relação ao capital e ao Estado, seja dentro de - ou entre - organizações como os sindicatos. Um sindicalismo que se pretenda democrático-radical e internacionalista mas que não entenda isto, está inevitavelmente condenado à estagnação. Além disso, a conectividade reticular sindical à escala internacional estagnará também 
se não perceber que faz parte de um projecto democrático-radical internacionalista cujo alcance vai muito para além dos sindicatos e dos problemas laborais.

"Conectividade reticular" é uma expressão que tem mais a ver com comunicação do que com instituições. Ora a conectividade internacional da esfera do trabalho, se não quiser reproduzir os valores dominantes do capitalismo GCI, tem que resultar - e tem que ser geradora - de um estilo de comunicação e de um sentido de cultura democrático-radical. Chamo a isto uma "cultura de solidariedade global". A ideia encontra expressão particularmente viva em Voices 21 (1999), produto de uma rede internacional de especialistas com uma prática democrática - universitários, activistas, etc. - ligados à área das comunicações. Este movimento preocupa-se com questões como o crescente acesso aos media, o direito a comunicar, a diversidade de expressão, a segurança e a privacidade. Tal como acima ficou referido, é notória a ausência, neste novo movimento social, das organizações sindicais internacionais. Isso deve-se, em parte, à autodefinição institucional dessas organizações, e em parte à circunstância de os trabalhadores das comunicações terem tendência a recear tanto as "interferências públicas" no seu território quanto receiam os magnatas dos media ou a censura estatal. Mas a esfera do trabalho tem uma história cultural longa e rica, e foi capaz, no passado, não só de inovar como inclusivamente de encabeçar movimentos culturais populares, democráticos, e até de vanguarda. O sindicalismo internacional tem, uma vez mais, de ultrapassar a sua autodefinição redutora. Caso contrário, permanecerá invisível na cena mediática internacional, a qual não só coloca cada vez mais desafios e exigências como se está mesmo a substituir aos espaços institucionais enquanto lugar por excelência da contestação e da deliberação democráticas.

O debate é a continuação da guerra por outros meios. A intenção é derrotar ou destruir o outro, quer se trate de uma ideia, um movimento ou uma pessoa. O conversar, por outro lado, implica ouvir o outro, mas sem que isso signifique necessariamente que essa troca seja ultrapassada ou transformada noutra coisa qualquer. Quanto ao diálogo, implica uma dialéctica, um processo através do qual as posições iniciais sofrem modificação até se chegar a uma nova síntese. Quando, acima, me referi ao diálogo do milénio sobre a esfera do trabalho a nível internacional, falava numa perspectiva simultaneamente descritiva e prescritiva. Há efectivos debates e conversas a decorrer neste momento; é bom que uns e outras assumam forma dialógica, tanto dentro como fora do movimento operário internacional (Waterman, 2001a).

Uma nota pessoal: Tendo vindo da tradição polemística do marxismo (incluindo o contributo de Lenine, cujas obras principais se acham desva- 
lorizadas devido ao carácter polémico da respectiva forma e intenção), tive que lutar para escapar dessa concha fechada, em direcção a algo mais parecido com uma conversa ou um diálogo. Uma outra concha, já se vê, é a "baba empolada dos académicos" (para usar a expressão com que, em 1990 - por alturas do final do Período Glaciar do último movimento operário internacional - um funcionário sindical internacional reagiu a um trabalho meu sobre uma lista de discussão relativa a questões laborais). O facto de ao menos ter sido capaz de entabular uma conversa pública com Bill Jordan, Secretário-Geral da CISL (Waterman, 2000), é já um pequeno sinal de que os tempos podem estar a mudar. Existem outros indícios de que, quando confrontadas com críticas públicas, as instituições internacionais ligadas ao mundo laboral estão a começar a ultrapassar o modo defensivo/agressivo. Ao longo dos últimos anos tenho-me visto envolvido de forma crescente em situações de diálogo significativo com pessoas ligadas ao mundo do trabalho e outros internacionalistas. Alguma dessa experiência vem contada na obra do académico e activista internacionalista Rob Lambert, embora o presente artigo talvez não deixe entrever que esse diálogo concreto começou há já 15 anos ou mais. Esse nosso diálogo, como é bom de ver, tem sido relativamente fácil, devido à amizade pessoal e ao respeito mútuo que nos une, muito embora também não tenha sido desprovido de tensão e de alguma frustração. Mais recentes, e também mais hesitantes, são as trocas públicas - ou privadas - que tenho vindo a manter com organizações e representantes sindicais a nível internacional. Se é certo que entre os meus amigos radicais ligados aos meios políticos e académicos estas conversas em privado podem ser consideradas um sinal não só de ingenuidade da minha parte, mas também de assimilação institucional, eu vejo esse conversar exactamente nos termos que acima referi, isto é, como uma experiência ou experimentação a partir da qual ambas as partes poderão posteriormente evoluir no sentido de um diálogo aberto. Seja como for, não estou interessado em manter conversas privadas - tal como não me interessa fazer consultas ou avaliações remuneradas - se não tiverem em vista permitir o aperfeiçoamento de intervenções públicas como esta, destinadas a fomentar o diálogo aberto. Gostaria que, não obstante as duras críticas que aqui lanço às instituições de tipo tradicional, essa intenção dialógica resultasse bem patente deste meu escrito. Assim os meus leitores me avisem, se não for esse o caso (e um deles já mo fez saber).

A vantagem da "Web" para abordar as questões relacionadas com o mundo do trabalho está em que ela não se limita a tornar mais fácil o diálogo internacional e internacionalista. Com efeito, a própria lógica do computador é uma lógica de retorno, de "feedback". A utilização unidireccional e cen- 
tralizadora do computador, em que um utente se dirige a muitos destinatários numa perspectiva de controlo, constitui a negação desta lógica e das possibilidades que encerra. Juntamente com a hipercapitalista "Web", a Internet - ela própria também, por vocação, eminentemente militar/industrial/ comercial/estatista - são subversoras das instituições e da institucionalização capitalistas. Recordem-se as palavras de Marx, escritas (mais uma vez, algo premonitariamente) há 150 anos a propósito do próprio capitalismo:

Todas as relações fixas e cristalizadas, com o seu séquito de preconceitos antigos e venerandas opiniões, são simplesmente postas de lado, e todas as que de novo se vão criando tornam-se antiquadas antes mesmo de terem tempo de ossificar. Tudo o que é sólido se dissolve no ar. (Marx e Engels, 1935: 209)

Não há outro modo de funcionar, neste nosso mundo globalizado e na "virtualidade real" (Castells, 1996-8: vol. I: 327-375) que o cerca e que literalmente o informa, que não seja vencendo este nosso medo de voar. Isso vai exigir de nós, enquanto internacionalistas ligados ao mundo do trabalho - quer nos situemos dentro das instituições, nas periferias destas, ou noutros-locais-mas-nem-por-isso-menos-interessados-no-problema-, que nos tornemos, para usar as palavras de Enzensberger (1976), "tão livres como o bailarino, argutos como o futebolista, e surpreendentes como o guerrilheiro". E isso, por sua vez, exige - de todos nós, mais uma vez que aprendamos a dialogar uns com os outros à medida que prosseguimos nas nossas lutas; e que, caminhando e falando, vamos construindo uma estrada que nos conduza para lá do capitalismo. ${ }^{26}$

\author{
Tradução de \\ Maria Teresa Tavares
}

\begin{abstract}
${ }^{26}$ Se esta afirmação evidencia um certa visão utópica, é porque a utopia também é necessária à reinvenção do internacionalismo operário. Ao criticar as interpretações contemporâneas do dilema com que nos debatemos, Ruth Levitas (2000) chama a atenção para a necessidade de aliarmos o utopismo dialógico (o processo) às antevisões do que será a sociedade pós-capitalista (o lugar). R. Levitas, no entanto, recorda que uma noção indiferenciada da transformação dialógica - ignorando, nomeadamente, os interesses cada vez mais conflituantes existentes no seio da sociedade capitalista contemporânea - terá como consequência que esses conflitos não sejam detectados, deixando-nos no mesmo ponto em que nos encontramos. Recorrendo a um exemplo relevante para o tema aqui em apreço, a autora ilustra o seu ponto de vista com um documento da Comissão Europeia que apela à "solidariedade" entre aqueles cujo "rendimento é ganho pelo trabalho que realizam e os que o ganham [sic] por meio de investimentos" (208-9; "sic" da autora citada - PW). E Levitas sugere ainda que uma base significativa para um diálogo transformador exige que se proceda a uma análise crítica do capitalismo, apostada não (só) em dizer que terrível que é, mas em identificar pontos potenciais de intervenção - que por seu turno possam levar a uma transformação - bem como agentes potenciais dessa mesma transformação (209).
\end{abstract}




\section{Lista das Siglas Principais}

AFL-CIO, American Federation of Labour-Congress of Industrial Organisations

$\mathrm{BC}$, bandeiras de conveniência

CISL, Confederação Internacional dos Sindicatos Livres

CLI, Comité de Ligação Internacional

CMA, Congresso para um Mundo Aberto

CMT, Confederação Mundial do Trabalho

FITT, Federação Internacional dos Trabalhadores dos Transportes

FSM, Federação Sindical Mundial

GCI, globalizado/conectado em rede/informatizado

NIC, nacional/industrial/colonial

OIT, Organização Internacional do Trabalho

ONGs, organizações não governamentais

SPIs, Secretariados Profissionais Internacionais

TIC, tecnologias da informação e da comunicação

\section{Referências Bibliográficas}

Ashwin, Sarah (2000), "International Labour Solidarity After the Cold War", in Robin Cohen; Shirin Rai (orgs.), Global Social Movements. London: Athlone, 101-116.

Barbrook, Richard (1999), "Frequently Asked Questions: Digital Work - Digital Workers and Artisans: Get Organised!”. Disponível em: <http://www.labournet.org/ 1999/March/digiwork.html>.

Bezuidenhout, Andries (1999), Towards Global Social Movement Unionism? Trade Union Responses to Globalisation in South Africa. Geneva: International Labour Organisation/International Institute for Labour Studies. 37 pp. Disponível em: <http:// www.ilo.org/public/english/bureauc/inst/papers/2000/dp115/>.

Brecher, Jeremy; Costello, Tim; Smith, Brendan (2000), Globalisation from Below: The Power of Solidarity. Massachusetts: South End.

Carew, Tony (2000), “A False Dawn: The World Federation of Trade Unions”, in Marcel van der Linden (org.), The International Confederation of Free Trade Unions. Bern: Peter Lang, 165-186.

Castells, Manuel (1996-8), The Information Age: Economy, Society and Culture. 3 Vols. Oxford: Blackwells.

China Labour Bulletin (2000), "ICFTU Delegation to China”, CLB \#35. Disponível em: <http://www.china-labour.org.hk/2005e/feature_icftu.htm>.

Couper, A. D. (1999), Voyages of Abuse: Seafarers, Human Rights and International Shipping. London: Pluto.

Enzensberger, Hans Magnus (1976), "Constituents of a Theory of the Media”, in Raids and Reconstructions: Essays in Politics, Crime and Culture. London: Pluto, 20-53. 
Escobar, Arturo (1999), "Gender, Place and Networks: A Political Ecology of Cyberculture”, in Wendy Harcourt (org.), Women@Internet: Creating New Cultures in Cyberspace, 31-55.

Fimmen, Edo (1924), Labour's Alternative: The United States of Europe of Europe Limited. London.

Gallin, Dan (1999a), “Organised Labour as a Global Social Force”, paper to a Workshop on International Relations plus Industrial Relations, Conference of the International Studies Association, Washington, February 20. Global Labour Institute, Geneva. Email: gli@iprolink.ch.

Gallin, Dan (1999b), "Trade Unions and NGOs in Social Development: A Necessary Partnership”, Paper for the United Nations Research Institute for Social Development, Geneva.38 pp.gli@iprolink.ch.

Gallin, Dan (2001), "Propositions on Trade Unions and the Informal Sector in Times of Globalisation", draft contribution to Peter Waterman and Jane Wills (orgs.), Place, Space and the New Labour Internationalisms. Oxford: Blackwells

Graham, Ian (1982a), “Computers of theWorld UNITE?”, Free Labour World, 1, 2-3.

Graham, Ian (1982b), "Programmed Solidarity? First Studies on a Union Computer Network", Free Labour World, 6, 32-33.

Gumbrell-McCormick, Rebecca (2000), "Facing New Challenges: The International Confederation of Free Trade Unions (1972-1990s)", in Marcel van der Linden (org.), The International Confederation of Free Trade Unions. Bern: Peter Lang, 341-518.

Hyman, Richard (1999a), “An Emerging Agenda for Trade Unions”. Disponível em: <http://www.ilo.org/public/english/bureau/inst/project/network/index.htm>.

Hyman, Richard (1999b), "National Industrial Relations Systems and Transnational Challenges”, European Journal of Industrial Relations, 5(1), 89-110.

ICFTU (2000a), "ICFTU Online... Global Compact an Opportunity for Global Dialogue. 31/07/00”. Disponível em: <http://www.icftu.org/>.

ICFTU (2000b), "The Global Compact: For a Socially Responsible Business World”, Trade Union World, 9, 22.

International Transportworkers Federation (1996), Solidarity - ITF Centenary Book. London: Pluto.

Jakobsen, Kjeld Aagard (2001), "Rethinking the International Trade Union Movement", in Peter Waterman; Jane Wills (orgs.), Place, Space and the New Labour Internationalisms. Oxford: Blackwells.

Jordan, Bill (2000), Remarks of Bill Jordan, ICFTU General Secretary, at the Reception of the International Conference "The Past and Future of International Trade Unionism”. Gent, 18 May 2000.

Klein, Naomi (2000), “Does Protest Need a Vision?”, New Statesman (UK), July 3, 23-25. 
Lambert, Rob; Webster, Eddie (1988), “The Re-emergence of Political Unionism in Contemporary South Africa?”, in William Cobbett; Robin Cohen (orgs.), Popular Struggles in South Africa. London: James Currey, 20-41.

Lambert, Rob (2001), "Southern Unionism and the New Internationalism", draft contribution to Peter Waterman and Jane Wills (orgs.), Place, Space and the New Labour Internationalisms. Oxford: Blackwells.

Lee, Eric (2000), The Internet Belongs To Everyone: A Radical View Of The Governance Of Cyberspace. Disponível em: <http://www.labourstart.org/icann/ericleebook. shtml>.

Levitas, Ruth (2000), "Discourses of Risk and Utopia”, in Barbara Adam; Ulrich Beck; Joost van Loon (orgs.), The Risk Society and Beyond: Critical Issues for Social Theory. London: Sage, 199-210.

Linden, Marcel van der (org.) (2000), The International Confederation of Free Trade Unions. Bern: Peter Lang.

MacShane, Dennis (1992), International Labour and the Origins of the Cold War. Oxford: Clarendon.

Marthoz, Jean-Paul (2000), "The Media and Globalisation”, Trade Union World, 7/8, 30 .

Marx, Karl; Engels, Frederick (1935), “The Manifesto of the Communist Party”, in Karl Marx: Selected Works. Vol. 1. Moscow: Cooperative Publishing Society of Foreign Workers in the USSR, 204-241 [1848].

Moody, Kim (1997), Workers in a Lean World: Unions in the International Economy. London: Verso.

Munck, Ronaldo (1988), The New International Labour Studies: An Introduction. London: Zed.

Munck, Ronaldo (2000), "Labour in the Global: Challenges and Prospects", in Robin Cohen; Shirin Rai (orgs.), Global Social Movements. London: Athlone, 83-100.

National Minority Movement (s.d.), Strike Strategy and Tactics. The Lessons of the Industrial Struggles. Thesis Adopted by the Strassburg Conference Held under the Auspices of the Red International of Labour Unions. [With foreword by P. Gladding]. 29 pp.

Open World Conference (2000a), <www.geocities.com/owc_2000>.

Open World Conference (2000b), "Open World Conference in Defence of Trade Union Independence and Democratic Rights”, OWC Report Back Bulletin, No. 1. San Francisco: Open World Conference. 64pp.

Reinalda, Bob (org.) (1997), The International Transportworkers Federation 1914-1945: The Edo Fimmen Era. Amsterdam: International Institute of Social History.

Sandri, Roger (1999), "Confronting Neo-Totalitarianism: Globalisation and the Struggle for Trade Union Independence”, Contribution for the Open World Conference of Workers in Defence of Trade Union Independence and Democratic Rights, San Francisco, February 2000. 90 pp. Disponível em: <http://www.geocities.com/owc_2000>. 
Scipes, Kim (1996), KMU: Building Genuine Trade Unionism in the Philippines, 1980-1994. Quezon City: New Day.

Seidman, Gay (1994), Manufacturing Militance: Workers' Movements in Brazil and South Africa, 1970-1985. Berkeley: California University Press.

South African Labour Bulletin (2000), "Com.Com: A Series of Irreverent Postcards. Our Inside Reporter Sends a Series of Postcards from Durban at the Time of the ICFTU Congress”, South African Labour Bulletin, 24(3), 112-16.

Trade Union World (1999), "Special 50th Anniversary Edition: How the ICFTU Has Influenced Global Developments Year After Year", Trade Union World, 7, 5-70.

Voices 21 (1999), "A Global Movement for People's Voices in Media and Communications in the 21st Century". Disponível em: <http://www.comunica.org/v21/ statement.htm>.

Waterman, Peter (1998a), Globalisation, Social Movements and the New Internationalisms. London: Mansell.

Waterman, Peter (1998b), "The Second Coming of Proletarian Internationalism? A Review of Recent Resources”, European Journal of Industrial Relations, 4(3), 349-7.

Waterman, Peter (1999), “International Labour's Y2K Problem: A Debate, a Discussion and a Dialogue (A Contribution to the ILO/ICFTU Conference on Organised Labour in the 21st Century)". Working Paper Series, No. 306. The Hague: Institute of Social Studies. 64 pp.

Waterman, Peter (2000), "From an International Union Congress to an International Labour Dialogue: An Exchange between Peter Waterman, Global Solidarity Dialogue/Dialogo Solidaridad Global, and Bill Jordan, General Secretary of the International Confederation of Free Trade Unions", disponível em: <http:// www.antenna.nl/ waterman $>$.

Waterman, Peter (2001a), Globalisation, Social Movements and the New Internationalisms. (Paperback) London: Continuum.

Waterman, Peter (2001b), "Capitalist Trade Privileges and Social Labour Rights in the Light of a Global Solidarity Unionism”.

Waterman, Peter; Wills, Jane (orgs.) (2001), Place, Space and the New Labour Internationationalisms. Oxford: Blackwells.

\section{Séries}

International Union Rights. International Centre for Trade Union Rights. UCATT House, 177 Abbeville Rd, London SW4 9RL, UK. Email: ictur@gn.apc.org.

Labour Notes. Labour Education and Research Project. 7435 Michigan Ave, Detroit MI 48210, USA. Email: labornotes@labornotes.org, Website: <http:// www.labornotes.org $>$.

Metal World. International Metalworkers Federation. POB 1516, 54 bis, route des Acasias, CH-1227 Geneva, Switzerland. Email: Sjutterstrom@imfmetal.org. 


\section{Vídeos}

Labour Battles the WTO in Seattle '99 - Workers of the World Unite. 38 min. VHS, NTSC. Labour Video Project, POB 425584, San Francisco, CA 94142, USA. Email: lvpsf@labornet.org.

Open World Conference in Defence of Trade Union Independence and Democratic Rights, San Francisco, February 11-14, 2000: Selected Speech Excerpts. VHS, NTSC. 60 min. OWC, c/o San Francisco Labour Council, 1188 Franklin St, Rm. 203, San Francisco, CA 94109. Email: owc@igc.org.

Showdown in Seattle: Five Days That Shook the WTO. VHS, NTSC. $150 \mathrm{~min}$. Independent Media Project/Deep Dish Television, 339 Lafayette Street, New York, NY 10012. Disponível em: <http://www.papertiger.org>.

\section{Websites}

Conference on Organised Labour in the 21st Century. <http://www.ilo.org/public/ english/bureau/inst/project/network/index.htm>

Global Labour Directory of Directories. <http://www.labourstart.org/gldod.shtml>

Global Solidarity Dialogue/Dialogo Solidaridad Global. <http://www.antenna.nl/ $\sim$ waterman/>

Global Compact: Human Rights, Labour, Environment. <http://www.unglobalcompact.org/> Global Unions. <http://www.global-unions.org/>

International Confederation of Free Trade Unions. <http://www.icftu.org >

Labor-List. LAB-L@YORK-U.CA

LaborMedia 99 Seoul Conference. <http://lmedia.nodong.net/archive_e.html>

LabourStart. <http://www.labourstart.org/>

Open World Conference. <http://www.geocities.com/owc_2000/>

SiD's Global Labour Summit. <http://www.antenna.nl/ waterman/>

Union Network International. <http://www.union-network.org >

Voices 21. <http://www.comunica.org/v21/statement.htm>

World Federation of Trade Unions. <http://www.wftu.cz $>$

Open Directory Project. <http://dmoz.org/society/organizations/labor/unions> 